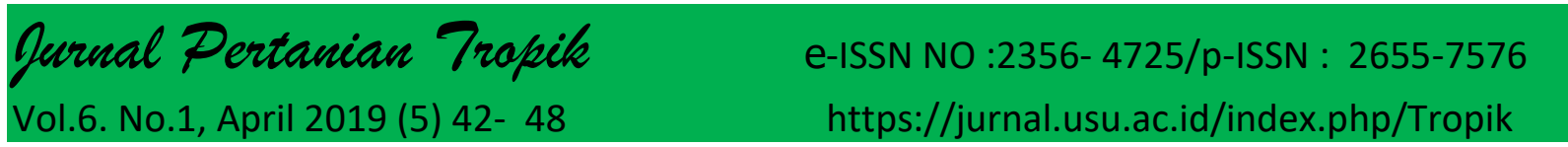

\title{
Klarifikasi Keanggotaan Manggis 'Malinau’ Dalam Species Garcina Mangostana Menggunkan Analisis Filogenik
}

'Malinau' Mangosteen Membership Classification in the Garcinia Mangostana Species Using Phylogeneous Analysis

Panca Jarot Santoso $^{\mathbf{1}^{*}}$, Ellina Mansyah ${ }^{\mathbf{1}}$, and Adi Pancoro ${ }^{2}$

${ }^{1}$ Balai Penelitian tanaman Buah Tropika, Balitbang Kementrian Pertanian, Sumbar, 27301

${ }^{2}$ Sekolah Ilmu dan Teknologi Hayati, Institut Teknologi Bandung

*Corresponding address: $\underline{70 \text { pjsantos@gmail.com }}$

\begin{abstract}
Phylogenetic analysis was conducted on 12 accessions of mangosteen (Garcinia mangostana L.) based on polymorphysm of conserved ITS-nrDNA gene. The research was conducted in Plant Genetic Laboratorium SITH-ITB and Breeding Laboratirum ITFRI from 2012 to 2014. Genomic DNA's were isolated from shoot leaves, meanwhile the ITS region were amplified using specific primers ITS5-F and ITS4-R. Phylogenetic tree was then constructed based on polymorphism of their DNA sequences using software Geneious ver. 5.5.7 and G. dulcis as outgroup. Based on the phylodendrogram constructed, it was found that all samples analyzed are generally monophyletic distributed, showing those are come from the same ancestor. Eleven of 12 samples are grouped in G. mangostana. However, as opposed to the generally view, 'Malinau' cultivar is confidently stand out of the group G. mangostana showing that this accession might be the different species. This fact is supported by the unique morphological characteristics of 'Malinau' compared to other 11 accessions.
\end{abstract}

Keywords: G. mangostana, Malinau, phylogeny, ITS-nrDNA

\begin{abstract}
ABSTRAK
Analisis filogenetik telah dilaksanakan terhadap 12 kasesi manggis (Garcinia mangostana L.) berdasarkan polimorfisme gen lestari ITS-nrDNA. Penelitian telah dilaksanakan di Laboratorium Genetika Tumbuhan SITH-ITB dan Laboratorium Pemuliaan Balitbu Tropika dari tahun 2012 sampai 2014. DNA genom diisolasi dari pucuk muda daun manggis. Daerah lestari ITS diamplifikasi menggunakan primer spesifik ITS5-F dan ITS4-R. Pohon filogenetik dikonstrusi berdasarkan polimorfisme dari sekuens ITS masing-masing aksesi menggunakan perangkat lunak Geneious ver. 5.5.7 menggunakan satu aksesi G. dulcis sebagai outgroup. Berdasarkan filodendrogram yang terbentuk, menunjukkan bahwa semua sampel yang dianalisis umumnya terdistribusi secara monofiletik, menunjukkan bahwa sampel-sampel tersebut berasal dari satu moyang yang sama. Sebelas dari 12 sampel telah tergroup dalam spesies G. mangostana, sebaliknya varietas 'Malinau' secara meyakinkan berada di luar group, yang menunjukkan bahwa 'Malinau' merupakan beda spesies dengan 11 sample lain yang digunakan dalam studi ini. Fakta ini didukung oleh karakteristik morfologi yang berbeda pada 'Malinau dibandingkan dengan 11 aksesi lainnya.
\end{abstract}

Kata kunci: G. mangostana, Malinau, filogenetik, ITS-nrDNA 


\section{PENDAHULUAN}

Manggis (Garcinia mangostana L.) adalah salah satu tanaman buah tropika yang bernilai tinggi dari kawasan Asia Tenggara termasuk Indonesia. Manggis merupakan anggota family Guttiferae bersama sekitar 400 spesies Garcinia di seluruh durian dan sekitar 100 spesies tumbuh di Indonesia (Richards, 1990; Hambali, 1996). Diantara seratus spesies, ada 22 spesies yang menghasilkan buah yang dapat dimakan (edibel), 21 spesies sebagai penghasil kayu, dan 58 spesies masih liar (Uji, 2007).

Tanaman manggis umumnya tumbuh liar di hutan dan ladang serta sebagian di lahan pekarangan. Disamping daging buahnya yang disukai karena memiliki rasa enak, pada dekade terakhir tanaman ini telah meningkat nilai ekonominya sejak ditemukannya kandungan bahan aktif xanton di dalam kulit manggis yang berguna sebagai obat herbal (Mahabusarakam et al. 2006). Sebagai akibat dari tingginya nilai ekonomi, pembudidayaan manggis di Indonesia sekarang juga sangat tinggi. Kondisi ini juga mendorong sejumlah peneliti untuk melakukan seleksi dari sumberdaya genetik indijenes dalam rangka menemukan varietas unggul. Sampai tahun 2015 ada 11 varietas manggis yang terdaftar di Kementrian Pertanian Republik Indonesia sebagai varietas unggul (Direktorat Benih Hortikultura, 2016).

Karakter manggis yang apomiksis (Rhichards, 1990., 1997) sering dijadikan dasar oleh para ahli botani untuk mengklaim tiadanya variasi diantara tanaman manggis. Apomiksis pada masa awal ditemukan diduga terjadi hanya pada manggis betina, tetapi menghasilkan biji yang fertile yang disebut apomiksis obligate (Rhichards, 1990., 1997). Proses apomiksis terjadi di dalam sel kelamin betina (ovule) tanpa persarian (fertilization) menghasilkan progeny yang secara genetik sama dengan tanaman induknya (Koltunow et.al. 1995). Berdasarkan teori ini, menyebabkan manggis diakui sebagai spesies tanaman buah dengan variasi genetik yang sempit dan dianggap sebagai klon tunggal.

Penelitian mutakhir pada tanaman manggis ternyata ditemukan adanya variasi fenotip dan genetik (Sobir et al., 2011). Variasi fenotip ditemukan pada bentuk kanopi, bentuk buah, warna bunga, panjang tangkai buah, stigma lobe, dll (Mansyah et al. 2003a). Variasi genetik juga dapat dibuktikan baik diantara individu dalam satu area tanaman maupun yang berbeda lokasi (Mansyah et al. 2003b; 2012). Variasi genetik juga ditunjukkan antara tanaman induk dengan progeni yang dihasilkan (Mansyah et al. 2004). Studi yang dilaksanakan oleh Ramage et. al., (2004) juga menunjukkan adanya variasi genetik diantara 37 aksesi manggis yang terbagi dalam tiga group yang berbeda.

Sebelas varietas unggul durian telah diseleksi dan didaftarkan di Kementrian Pertanian untuk tujuan komersialisasi (Ditbenih, 2016), namun demikian, semua varietas ini merupakan hasil pemutihan dari varietas indigenous dari berbagai daerah, sehingga belum diketahui sepenuhnya asalusulnya terutama berkaitan status kekerabatan genetik diantara varietas tersebut. Di kalangan pemerhati manggis ternyata memiliki berbagai ragam pendapat berkaitan dengan variasi manggis yang telah dilepas tersebut. Diantara varietas yang terdaftar, terdapat satu aksesi yang cukup unik yaitu manggis Malinau (Siregar et al. 2013), yang memiliki ukuran buah dan daun yang ekstra besar dibandingkan dengan varietas yang lain. Walaupun secara umum disebut sebagai manggis biasa dan masuk dalam G. mangostana, karakter yang 
sangat berbeda ini mendorong perlunya untuk dilakukan pengujian lebih lanjut untuk informasi yang lebih terpercaya.

Tujuan dari studi ini adalah untuk menganalisis 12 aksesi manggis dalam rangka validasi posisi manggis Malinau diantara varietas manggis lainnya.

\section{BAHAN DAN METODE}

Penelitian telah dilaksanakan di Laboratorium Genetika Tumbuhan, Sekolah Ilmu dan Teknologi Hayati, Institut Teknologi Bandung dan Laboratorium Pemuliaan Tanaman, Balai penelitian tanaman Buah Tropika dari tahun 2012 sampai 2014. Materi tanaman terdiri atas 12 aksesi manggis dan satu aksesi dari kerabat manggis yaitu mundu (G. dulcis). Sampel berupa pucuk daun disimpan dalam bentuk spesimen kering dalam silika gel biru.

Daun manggis muda yang belum terbuka sempurna dikoleksi dari pohon manggis dan disimpan dalam kantong plastik berisi silica-gel sebagai bahan untuk isolasi DNA genom. Isolasi DNA dilaksanakan menggunakan metode berdasarkan Geneaid ${ }^{\mathrm{TM}}$ Mini Preparation Kit dengan beberapa modifikasi. DNA hasil isolasi kemudian diamplifikasi menggunakan protokol PCR dengan primer spesifik ITS5 (5'-TAG AGG AAG GAG AAG TCG TAA CAA-3') dan ITS4 (5'CCC GCC TGA CCT GGG GTC GC 3'). PCR meliputi tahap pre-denaturasi DNA pada suhu $94{ }^{\circ} \mathrm{C}$ selama 3 menit. Selanjutnya amplifikasi dilakukan dengan satu macam siklus yang diulang $25 \mathrm{kali}$, yaitu denaturasi pada suhu $94^{\circ} \mathrm{C}$ selama 30 detik, diikuti annealing pada suhu $55^{\circ} \mathrm{C}$ selama 30 detik dan elongasi pada suhu $72^{\circ} \mathrm{C}$ selama 1 menit. Amplifikasi diakhiri dengan tahap elongasi pada suhu $72{ }^{\circ} \mathrm{C}$ selama 5 menit.

Elektroforesis dilaksanakan untuk memastikan keberhasilan proses amplifikasi. Setiap $5 \mu$ amplikon ditambah $1 \mu$ l loading dye selanjutnya dimasukkan kedalam sumur gel agarose $1 \%$ di dalam chamber elektroforesis yang dipasang pada daya listrik 100 volt selama 15-25 menit. Setelah elektroforesis, gel di rendam dalam larutan $0.01 \%$ ethidium bromide selama 10 15 menit kemudian dipindai di atas UVtransiluminator.

Tabel 1. Aksesi manggis dan kerabat manggis yang digunakan pada kegiatan penelitian

\begin{tabular}{lllllll}
\hline \multirow{2}{*}{ Aksesi } & \multicolumn{5}{c}{ Karakter Morfologi } \\
\cline { 2 - 6 } & $\begin{array}{l}\text { Ukuran } \\
\text { daun }\end{array}$ & $\begin{array}{l}\text { Ukuran } \\
\text { buah }\end{array}$ & $\begin{array}{l}\text { Bentuk } \\
\text { buah }\end{array}$ & $\begin{array}{l}\text { Warna } \\
\text { buah }\end{array}$ & $\begin{array}{l}\text { Bentuk } \\
\text { biji }\end{array}$ & $\begin{array}{l}\text { Ukuran } \\
\text { biji }\end{array}$ \\
\hline Mundu & sedang & sedang & Oval & kuning & oval & besar \\
Kaligesing & sedang & sedang & membulat & ungu & irreguler & kecil \\
Wanayasa & sedang & sedang & membulat & ungu & irreguler & kecil \\
Puspahiang & sedang & sedang & membulat & ungu & irreguler & kecil \\
Lingsar & sedang & sedang & membulat & ungu & irreguler & kecil \\
Kamang & sedang & sedang & membulat & ungu & irreguler & kecil \\
Tembilahan & sedang & sedang & membulat & ungu & irreguler & kecil \\
Katingan & sedang & sedang & membulat & ungu & irreguler & kecil \\
Jambi & sedang & sedang & membulat & ungu & irreguler & kecil \\
Mappa & sedang & sedang & membulat & ungu & irreguler & kecil \\
Lotan & sedang & sedang & membulat & ungu & irreguler & kecil \\
Kerang dayo & sempit & kecil & membulat & ungu & irreguler & kecil \\
Malinau & lebar & besar & membulat & ungu & seedless & - \\
\hline
\end{tabular}




\section{Sekuensing dan penyusunan pohon filogenetik}

Sekuensing hasil amplifikasi dikerjakan secara direct-sequencing dengan menggunakan jasa pelayanan sekuensing di Macrogen, Korea. Data hasil sekuensing diolah menggunakan perangkat lunak Geneious (Drummond et al., 2011) untuk membangun pohon filogenetik manggis unggul.

\section{HASIL DAN PEMBAHASAN}

Amplifikasi sampel DNA genom dari 13 aksesi manggis diperoleh produk dengan panjang sekitar 700-800 nukleotida sesuai dengan panjang sekuens gen ITSnrDNA yang dilaporkan oleh Baldwin dkk., (1995). Penjajaran yang dilakukan terhadap 13 sekuens menunjukkan semua aksesi memiliki sekuens yang unik dan berbeda satu sama lain, untuk melihat kedudukan masing-masing aksesi, selanjutnya dilakukan rekonstruksi pohon filogenetik dengan aksesi mundu sebagai outgroup, dan hasil rekonstruksi pohon filogenetik ditampilkan pada Gambar 1.

Gambar 1 menunjukkan bahwa
pohon filogenetik tersusun secara
monofiletik yang menggambarkan alur
evolusi dari yang tertua sampai yang
termuda, dimana posisi tertinggi ditempati
oleh Mundu yang telah disepakati sebagai
spesies diluar G. mangostana. Hasil

rekonstruksi menunjukkan bahwa susunan yang meyakinkan dengan nilai bootstrap 100 antara klaster 1 dan 2, sedangkan pada klaster ketiga bernilai bootstrap 74.15. Berdasarkan rekonstruksi pohon filogenetik, secara umum ke-13 sampel terpisah menjadi 3 kluster dengan klaster pertama dan kedua yang terisi oleh masingmasing satu aksesi yaitu Mundu di klster pertama dan Malinau di klaster kedua, sedangkan klaster ketiga ditempati oleh 11 aksesi manggis lainnya.

Filodendrogram ini menunjukkan bahwa 11 aksesi yang berada dalam satu klaster yang mengindikasikan suatu konfirmasi bahwa aksesi-aksesi ini berada dalam satu spesies yang sama. Demikian juga mundu yang dari semula telah di sepakati sebagai spesies yang berbeda juga terkonformasi dengan posisinya yang tersendiri dan berada pada puncak filogram. Sedangkan aksesi manggis Malinau dengan posisi yang berbeda dari group 11 manggis lainnya dan membentuk klaster sendiri menunjukkan bahwa manggis Malinau merupakan spesies tersendiri berbeda dengan Garcinia mangostana L. Hasil ini berbeda dengan pemahaman umum bahwa manggis Malinau adalah termasuk dalam spesies G. mangostana. Berdasarkan hasil penelitian ini kiranya perlu dilakukan identifikasi dan pemberian nama spesies baru untuk manggis Malinau. 


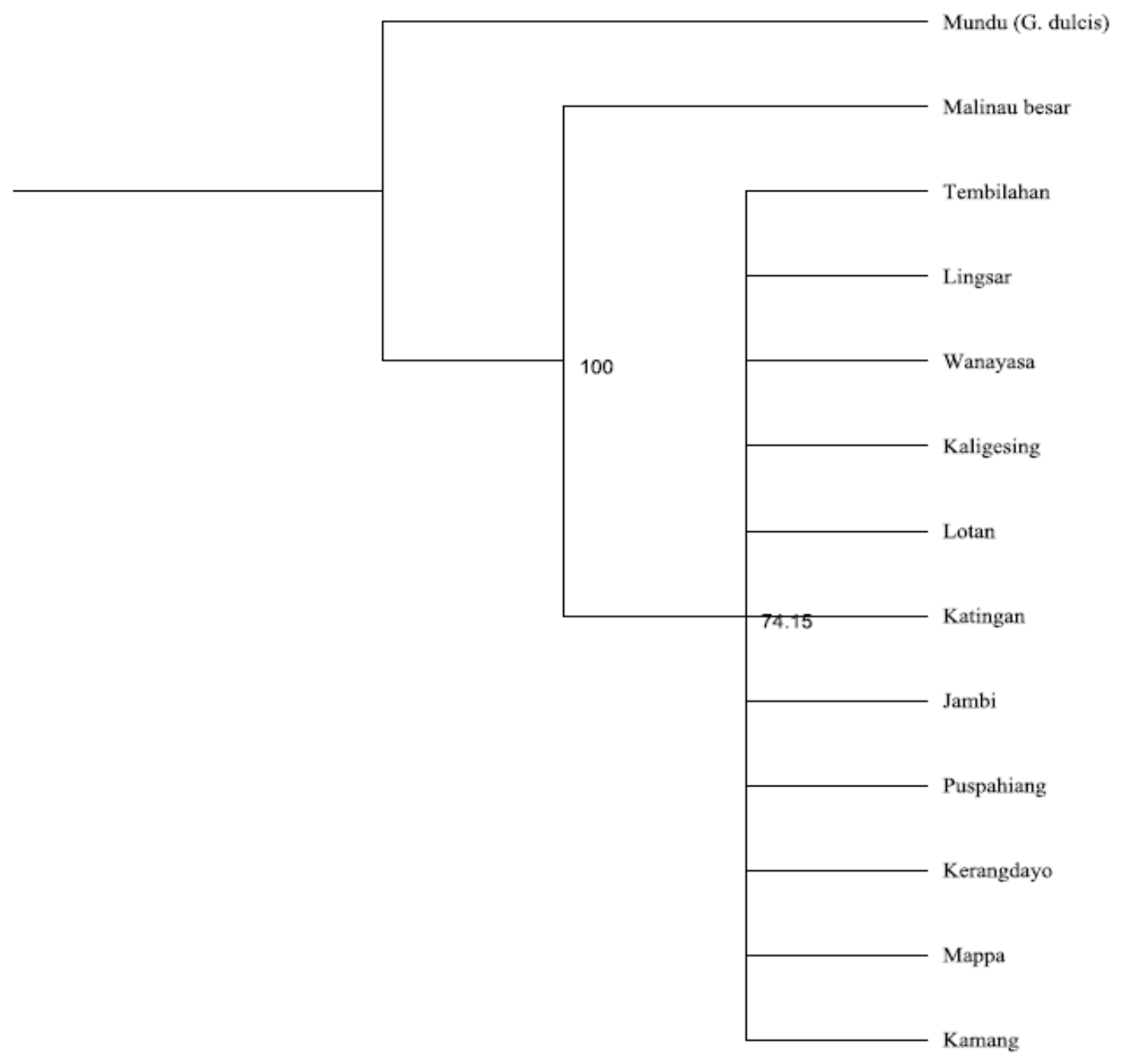

Gambar 1. Rekonstruksi pohon filogenetik 13 aksesi manggis menggunakan sekuens ITSnrDNA

\section{SIMPULAN}

Hasil analisis ini menunjukkan bahwa manggis Malinau berbeda dengan aksesi manggis yang masuk dalam spesies G. mangostana dan diduga merupaka spesies tersendiri.

\section{DAFTAR PUSTAKA}

Astuti, R., Marimin, Machfud, Y Arkeman, $\mathrm{R}$ Poerwanto, MPM Meuwissen
(2013). Risks and Risks Mitigations in the Supply Chain of Mangosteen: A Case Study. Operation dan Supply Chain Management 6(1): 11 - 25. ISSN 1979-3561| EISSN 1979-3871 Baldwin, B. G., Sanderson, M. J., Porter, J. M., Wojeiechowski, M. F., Champbell, C. S. dan Donoghue, M. J. (1995). The ITS region of nuclear ribosomal DNA: A valuable source of evidence of angiosperm phylogeny. Annals of Missouri Botanical Garden, 82(2), 247-277. 
Direktorat Perbenihan Hortikulutra (2016). Database Varietas Terdaftar Hortikultura. http://varitas.net/dbvarietas/cari.php? type $=$ varietas $\& q=\&$ komoditas $=* \& S u$ bmit=Search

Drummond, A. J., Ashton, B., Buxton, S., Cheung, M. dan Cooper, A. (2011). Geneious v4.8.

http://www.geneious.com/.

Diunduh pada 9 Januari 2012.

Hambali, G.G. 1996. Eksplorasi dan koleksi kerabat liar tanaman manggis di Indonesia. Paper disajikan acara Diskusi Ilmiah mengenai Teknologi Budidaya Tanaman Manggis, pada 15 Juni 1996. Bogor.

Siregar, IZ, N Khumaida, D Noviana, MH Wibowo, \& Azizah. 2013. Varietas Tanaman Unggul Institut Pertanian Bogor. Direktorat Riset dan Inovasi IPB. 46 hlm. ISBN 978-979-493-3053

Koltunow AM, Bicknell RA, Chaudhury AM (1995) Apomixis: molecular strategies for the generation of genetically identical seeds without fertilization. Plant Physiol 108: 13451352.

Mahabusarakam W, Kuaha K, Wilairat P, Taylor WC (2006) Prenylated xanthones as potential antiplasmodial substances. Planta Medica 72:912916

Mansyah, E., A Baihaki, Ridwan Setiamihardja, Juliati S. Darsa, Sobir, dan R. Poerwanto. (2003a). Variabilitas fenotipik manggis pada beberapa sentra produksi di Pulau Jawa. Jurnal Hortikultura 13 (3): pp147-156.

Mansyah, E., A Baihaki, Ridwan Setiamihardja, Juliati S. Darsa,dan Sobir. (2003b). Analisis variabilitas genetik manggis (Garcinia mangostana L.) di Jawa dan Sumatera Barat menggunakan teknik RAPD. Zuriat. 14(1): pp 35-44

Mansyah, E, Sobir, E Santosa \& R Poerwanto (2010). Assessment of inter simple sequence repeat (ISSR) technique in mangosteen (Garcinia mangostana L.) grown in different Sumatra region. Journal of Horticulture and Forestry Vol. 2(6) pp. 127-134

Mansyah E, Anwarudinsyah MJ, Usman F, Purnama T (2004) Genetic variability between parental tree (Garcinia mangostana $\mathrm{L}$.) and their progenies. $J$ Hortikultura 14: 229-237.

Mansyah E, PJ Santoso, I Muas, \& Sobir (2013). Evaluation of genetic diversity among and within mangosteen (G. mangostana L) trees. Acta Hortic. 975, 73-79 DOI: 10.17660/ActaHortic.2013.975.6

José Pedraza-Chaverri Noemí CárdenasRodríguez, Marisol Orozco-Ibarra, Jazmin M. Pérez-Rojas (2008). Medicinal properties of mangosteen (Garcinia mangostana). Food and Chemical Toxicology 46:3227-3239

Ramage CM, Sando L, Peace CP, Carol BJ, Drew RA (2004) Genetic diversity revealed in the apomictic fruit species Garcinia mangostana L. (mangosteen). Euphytica 136: 1-10.

Richards AJ (1990) Studies in Garcinia, dioecious tropical forest trees: the origin of the mangosteen. Bot J Linn Soc 103: 301-308

Richards AJ (1997) Plant breeding systems. 2nd ed. Chapman and Hall. London

Shan, T., Q Ma, K Guo, J Liu, W Li, F Wang \& E Wu (2011). Xanthones from Mangosteen Extracts as Natural Chemopreventive Agents: Potential Anticancer Drugs. Curr Mol Med, 11(8): 666-677 


Devnal Pertanian Tropile e-ISSN NO :2356- 4725/p-ISSN : 2655-7576
Vol.6. No.1, April 2019 (5) $42-48$

Sobir, Poerwanto R, Santosa E, Sinaga S, Mansyah E (2011) Genetic variability in apomictic mangosteen (Garcinia mangostana) and its close relatives (Garcinia spp.) based on ISSR markers. Biodiversitas 12: 5963.

Uji T (2007) Diversity, distribution and potential of genus Garcinia in Indonesia. Hayati 12: 129-135 